\title{
PENEMUAN HUKUM OLEH HAKIM MELALUI PEMBUKTIAN DENGAN MENGGUNAKAN BUKTI ELEKTRONIK DALAM MENGADILI DAN MEMUTUS SENGKETA PERDATA
}

\author{
Efa Laela Fakhriah ${ }^{a}$
}

\begin{abstract}
ABSTRAK
Berdasarkan sistem hukum acara perdata yang berlaku, hakim terikat pada alat-alat bukti yang sah, yang berarti bahwa hakim hanya boleh menjatuhkan putusan berdasarkan alat-alat bukti yang ditentukan oleh undang-undang saja sebagaimana diatur dalam Pasal 164 HIR. Di samping itu juga alat bukti pemeriksaan setempat sebagaimana dan keterangan saksi ahli Hukum pembuktian yang berlaku saat ini, secara formal belum mengakomodasi dokumen elektronik sebagai alat bukti, sedangkan dalam praktiknya di masyarakat melalui transaksi perdagangan secara elektronik, alat bukti elektronik sudah banyak digunakan, terutama dalam transaksi bisnis modern. Tulisan ini menghasilkan simpulan bahwa dalam hal memeriksa perkara yang pembuktiannya menggunakan bukti-bukti bersifat elektronik, karena hukum acara perdata (HIR) sebagai hukum formil tidak mengaturnya, maka hakim dapat mendasarkan pembuktian pada hukum materiil yang juga mengatur tentang hukum acara, dalam hal ini Undang-undang Informasi dan Transaksi Elektronik atau Undang-undang Dokumen Perusahaan. Akan tetapi seandainya pun tidak ada peraturan materil yang mengatur tentang bukti elektronik sebagai alat bukti yang sah dipersidangan, atau hakim tidak mau mendasarkan pembuktian pada hukum materiil, hakim dapat melakukan penemuan hukum dengan cara analogi atau penafsiran hukum terhadap bukti yang bersifat elektronik agar dapat digunakan sebagai alat bukti di persidangan sebagaimana halnya alat bukti yang diatur dalam hukum acara perdata.
\end{abstract}

Kata kunci: bukti elektronik; pembuktian; penemuan hukum.

\section{ABSTRACT}

According to the Civil Procedural Law system, the judges were bound to the legal evidences, which meant that the judges might only impose the verdict based on legal evidences which determined by the law as stated in Article 164 HIR for instances: documentary evidence, witness' statement, allegation, recognition, and oath. In addition, the local inspection as legal evidence was also regulated in Article 153 HIR, and the expert statement stipulated in Article 154 HIR. The current of evidentiary law, was not accommodating electronic documents yet as legal evidence, while in fact electronic trading transactions among societies needed electronic evidence had been widely used, especially in modern business transactions. The problem was how the judge conducted a legal discovery in giving verdict in lawsuit dispute which was handled to use electronic evidence as legal evidence, in the other hand, according to the Civil Procedural Law system stated that evidentiary was legitimate when done using the evidence that had been determined/regulated in the Civil Procedural Regulation.

Keywords: electronic evidence; evidentiary; legal discovery. 


\section{PENDAHULUAN}

Pembangunan Nasional merupakan usaha peningkatan kualitas manusia, dalam hal ini masyarakat Indonesia, pada berbagai aspek kehidupan yang dilakukan secara berkelanjutan berlandaskan pada kemampuan nasional, dengan memanfaatkan kemajuan ilmu pengetahuan dan teknologi serta memperhatikan perkembangan global. Salah satu aspek dalam pembangunan hukum nasional yaitu aspek legislasi yang antara lain meliputi pembentukan hukum. Pembentukan hukum merupakan salah satu bentuk penemuan hukum, karena dalam arti luas penemuan hukum meliputi kegiatan-kegiatan pembentukan hukum, penerapan hukum dan penegakan hukum.

Penemuan hukum bukan semata-mata hanya penerapan peraturan hukum terhadap peristiwa konkrit, tetapi sekaligus juga penegakan hukum dan pembentukan hukum. Penemuan hukum merupakan proses konkretisasi dan individualisasi peraturan hukum yang bersifat umum dengan mengingat peristiwa konkrit, dengan bersumber pada peraturan perundang-undangan, hukum kebiasaan, yurisprudensi, perjanjian internasional, dan doktrin, yang merupakan sumber utama hukum penemuan hukum.

Penemuan hukum oleh hakim diutamakan karena seyogyanya tugas utama hakim adalah menemukan hukum dalam mengadili dan memutus suatu perkara, dan melakukan pembentukan hukum melalui putusannya (yurisprudensi) yang merupakan salah satu sumber hukum. Di samping itu ilmuwan hukum juga melakukan penemuan hukum, hasilnya berupa ilmu hukum atau doktrin yang juga dapat dijadikan sumber hukum. Doktrin kalau diikuti dan diambil alih oleh hakim dalam putusannya maka menjadi hukum.

Pada umumnya problematika penemuan hukum, dipusatkan pada hakim dan pembentuk undang-undang. Hakim selalu melakukan penemuan hukum karena hakimlah yang sering dihadapkan kepada peristiwa konkrit atau konflik untuk diselesaikannya. Sebagaimana ditentukan dalam Pasal 11 ayat (3) UU Nomor 48 Tahun 2009 tentang Kekuasaan Kehakiman (untuk selanjutnya disebut UU Kekuasaan Kehakiman) ditentukan bahwa hakim dalam memeriksa, mengadili dan memutus perkara dibantu oleh seorang panitera. Dari ketentuan tersebut diketahui bahwa tugas pokok hakim adalah memeriksa, mengadili dan memutus perkara. ${ }^{1}$

Seiring dengan berkembangnya ilmu pengetahuan di bidang teknologi dan informasi yang mempengaruhi kehidupan masyarakat global, antara lain ditandai dengan era teknologi informatika yang memperkenalkan dunia maya dengan hadirnya internet (interconnected network). Internet telah membentuk masyarakat dengan kebudayaan baru, saat ini hubungan antara masyarakat dalam dimensi global tidak lagi dibatasi oleh batas-batas territorial negara (borderless). Hadirnya internet

\footnotetext{
1 Elisabeth Nurhaini Butarbutar, "Arti Pentingnya Pembuktian dalam Proses Penemuan Hukum di Peradilan Perdata", Jurnal Mimbar Hukum, Vol. 22, No. 2, 2010, hlm. 347.
} 
Penemuan Hukum oleh Hakim Melalui Pembuktian dengan Menggunakan Bukti Elektronik

dengan segala fasilitas dan program yang menyertainya, seperti: e-mail, chating video, video teleconference, dan situs website $(w w w)$, telah memungkinkan dilakukannya komunikasi global tanpa mengenal batas negara.

Hal ini menimbulkan perubahan dalam berbagai aspek kehidupan bermasyarakat. Perubahan juga terjadi dalam hal macam-macam bukti yang dapat digunakan dalam penyelesaian sengketa perdata melalui pengadilan, dengan dikenal dan digunakannya bukti elektronik dimasyarakat. Hukum pembuktian di Indonesia belum mengakomodasi keberadaan dokumen/data elektronik sebagai alat bukti, sementara dalam perkembangannya sekarang dikenal adanya bukti elektronik baik berupa dokumen/data elektronik maupun keluaran komputer lainnya.

Secara materiil mengenai bukti elektronik ini sudah termuat dalam berbagai peraturan perundang-undangan, seperti antara lain dalam UU No 8 Tahun 1997 tentang Dokumen Perusahaan serta UU No 11 Tahun 2008 tentang Informasi dan Transaksi Elektronik, namun secara formal dalam hukum acara (termasuk dalam Rancangan Undang Undang Hukum Acara Perdata) belum diatur tentang bukti elektronik.

Dalam melakukan penemuan hukum, hakim dapat melakukan penafsiran hukum untuk mengisi kekosongan undang-undang. Sebenarnya dalam dunia hukum sudah sejak lama dilakukan perluasan penafsiran asas dan norma hukum ketika menghadapi persoalan yang tidak berwujud. Misalnya dalam putusan tentang kasus pencurian aliran listrik (tidak berwujud), yang pada awalnya sulit dikategorikan sebagai delik pencurian tetapi pada akhirnya dengan penafsiran hukum, aturan hukum tentang pencurian dapat diperluas sehingga menjangkau pula benda yang tidak berwujud (aliran listrik) dan perbuatan pencurian aliran listrik tersebut dapat diterima sebagai perbuatan pidana. $^{2}$

Penemuan hukum dalam acara perdata boleh dilakukan, tetapi jangan sampai melanggar atau mengesampingkan teori-teori penemuan hukum yang benar. Penemuan hukum tidak dapat asal saja dilakukan, melainkan ada metode atau aturan permainannnya yang tetap harus diikuti. Metode penemuan hukum terdiri dari penafsiran hukum dan konstruksi hukum. Penafsiran hukum terdiri dari penafsiran historis, penafsiran sistematis, penafsiran gramatikal dan penafsiran teleoligis, sedangkan konstruksi hukum meliputi analogi, argumentum a-contrario dan penghalusan hukum.

Metode penemuan hukum hanya dipergunakan dalam praktik hukum, terutama oleh hakim dalam rangka mengadili suatu perkara. Metode penemuan hukum diarahkan pada suatu peristiwa yang bersifat khusus, konkret dan individual. Penemuan hukum dibatasi oleh peraturan-peraturan hukum, dalam melakukan penemuan hukum seorang hakim dibatasi oleh Pasal 21 AB (Algemene

\footnotetext{
2 Yurisprudensi, Electriciteits Arrest, 23 Mei 1921.
} 
Bepalingen van Wetgeving) yang menyatakan bahwa pada pokoknya seorang hakim tidak boleh memberi keputusan yang akan berlaku sebagai peraturan umum. ${ }^{3}$

Pertanyaan yang kemudian menarik untuk diteliti adalah terkait bagaimanakah sikap hakim dalam melakukan penemuan hukum dalam memutus suatu perkara yang ditanganinya terkait dengan pembuktian alat bukti elektronik? dan, bagaimanakah sistem hukum acara perdata mengakomodasi pengaturan bukti elektronik di Indonesia jo. UU Informasi dan Transaksi Elektronik dan UU Dokumen Perusahaan?

Artikel ini merupakan sari dari penelitian yang telah selesai dilakukan dengan permasalahan pengaturan alat bukti elektronik pada sistem peradilan perdata dan implikasi penemuan hakim dalam menilai kekuatan pembuktian alat bukti elektronik di dalam persidangan. Sementara itu, maksud atau tujuan daripada penelitian ini adalah untuk menganalisis permasalahan atas ketiadan aturan formil terkait pengaturan alat bukti elektronik di Pengaturan Bab Pembuktian Hukum Acara Perdata dan upaya hakim dalam melakukan penemuan hukum demi terpenuhinya asas Ius Curia Novit.

\section{PEMBAHASAN}

Sikap Hakim dalam Melakukan Penemuan Hukum dalam Memutus Suatu Perkara yang Ditanganinya Terkait dengan Pembuktian Alat Bukti Elektronik

Pasal 5 ayat (1) UU No. 48 Tahun 2009 Tentang kekuasaan Hakim (UU Kekuasaan kehakiman) mengatur: "Hakim dan Hakim Konstitusi wajib menggali, mengikuti, dan memahami nilainilai hukum dan rasa keadilan yang hidup dalam masyarakat". Dalam penjelasannya, dijelaskan pengaturan Pasal tersebut agar putusan hakim dan Hakim Konstitusi sesuai dengan hukum dan rasa keadilan masyarakat. Berdasarkan ketentuan yang demikian, hakim dituntut tidak hanya menegakkan hukum undang - undang semata, tetapi diwajibkan untuk menggali, mengikuti dan memahami nilai dan rasa keadilan masyarakat. Pada konteks ini UU Kekuasaan Kehakiman menegaskan bahwa hakim Indonesia bukanlah corong undang - undang semata.

Penegasan normatif di atas, secara legal formal terbuka ruang penemuan hukum oleh hakim. Kewenangan penemuan hukum dibuka untuk memberikan penjelasan terhadap ketentuan undangundang yang belum jelas atau melengkapi pengaturan normatif yang tidak lengkap dan dimungkinkan untuk mengisi kekosongan hukum dari suatu undangundang. Ketidak-lengkapan, ketidak-jelasan dan kekosongan hukum ini merupakan konsekuensi dari sebuah realitas bahwa "teks" undang-undang yang tidak selalu sempurna. Apalagi laju undang-undang yang statis dibandingkan dengan perkembangan masyarakat maka sifatnya sebatas moment opname sehingga

\footnotetext{
${ }^{3}$ Teguh Prasetyo-Abdul Halim Barkatullah, Ilmu Hukum \& Filsafat Hukum, Pustaka Pelajar, Yogyakarta: 2007, hlm. 25.
} 
Penemuan Hukum oleh Hakim Melalui Pembuktian dengan Menggunakan Bukti Elektronik

harus di "kontekstualisasi" kan oleh hakim. Dalam hal ini hakim harus menafsirkan dan atau menggali kandungan norma yang terdapat di dalam undang-undang itu sehingga sesuai dengan perkembangan nilai dan rasa keadilan masyarakat. ${ }^{4}$

Proses penyelesaian sengketa perdata melalui pengadilan terdiri dari beberapa tahapan, dimulai dari pengajuan gugatan oleh Penggugat, penyampaian jawaban oleh Tergugat atas gugatan Penggugat, kemudian replik dari Penggugat dan duplik dari Tergugat. Tahap berikutnya adalah pembuktian yang merupakan kewajiban para pihak, dilanjutkan dengan penarikan kesimpulan berdasarkan hasil pembuktian oleh para pihak atas dalil-dalil yang diajukannya, kemudian kesimpulan disampaikan kepada hakim sebagai bahan bagi hakim untuk memberikan pertimbangan berdasarkan hukum maupun faktanya dalam menjatuhkan putusan atas suatu perkara.

Dalam proses penyelesaian sengketa perdata di pengadilan, acara pembuktian menempati posisi penting karena fungsi pembuktian adalah berusaha memberikan kepastian tentang kebenaran fakta hukum yang menjadi pokok sengketa bagi hakim ${ }^{5}$, karenanya hakim akan selalu berpedoman pada hasil pembuktian dalam menjatuhkan putusan atas perkara yang ditanganinya.

Tujuan pembuktian adalah untuk memperoleh kepastian bahwa suatu peristiwa atau fakta yang diajukan itu benar-benar terjadi guna mendapatkan putusan hakim yang benar dan adil. Hakim tidak dapat menjatuhkan suatu putusan sebelum nyata baginya bahwa fakta atau peristiwa yang diajukan itu benar terjadi, yakni dibuktikan kebenarannya sehingga tampak adanya hubungan hukum antara para pihak. ${ }^{6}$

Menurut undang-undang mengenai alat bukti dalam perkara perdata ini diatur secara limitatif dan berurutan dalam HIR/RBg. Dalam Pasal 164 HIR/284 RBg, secara limitatif disebutkan bahwa ada lima macam alat bukti yang dapat digunakan, yaitu bukti tertulis (surat), keterangan saksi, persangkaan-persangkaan, pengakuan, dan sumpah. Di luar Pasal 164 HIR/284 RBg, dikenal juga alat bukti pemeriksaan setempat (Pasal 153 HIR/180 RBg) yang berdasarkan yurisprudensi merupakan alat bukti, dan keterangan saksi ahli (Pasal $154 \mathrm{HIR} / 181 \mathrm{RBg}$ ) yang meskipun belum secara formal dinyatakan sebagai alat bukti namun banyak digunakan dalam praktek di masyarakat.

Alat bukti dalam perkara perdata mengalami perkembangan dengan dikenalnya beberapa alat bukti yang tidak diatur dalam undang-undang, seperti: foto copy, foto (potret), hasil rekaman suara maupun gambar, fax, serta bukti-bukti elektronik yang dijadikan sebagai alat bukti, seperti misalnya antara lain: surat elektronik (e-mail), pemeriksaan saksi menggunakan video teleconference, sistem layanan pesan singkat (sms: short massage system), dan data/dokumen elektronik lainnya.

\footnotetext{
4 Budi Suhariyanto, "Eksistensi Pembentukan Hukum oleh Hakim dalam Dinamuka Politik Legislasi di Indonesia", Jurnal Rechsvinding, Vol 4, No. 3, Desember 2015, hlm. 413.

5 Bachtiar Efendi dkk, Surat Gugatan dan Hukum Pembuktian Dalam Perkara Perdata, Citra Aditiya Bakti, Bandung: 1991 , hlm. 50.

6 A. Mukti Arto, Praktek-praktek Perdata pada Pengadilan Agama, Pustaka Pelajar, Yogyakarta: 2003, hlm. 140.
} 
Untuk menutupi celah kesenjangan dan keberpihakan dalam proses politik legislasi yang menghasilkan kontra produktif dengan kepentingan dan kebutuhan rakyat atau masyarakat terhadap hukum yang aktual dan kongkret, maka hakim harus mengambil peranan. Melalui penemuan hukum, hakim dapat menghindarkan para pencari keadilan dari ketertindasan pelaksanaan produk hukum (undang-undang) yang tidak adil. Bahkan melalui pembentukan hukum baru, baik hakim maupun Pengadilan dapat berperan secara strategis dalam pembinaan hukum nasional dengan mewujudkan berbagai fungsi melalui putusan-putusannya. Fungsi tersebut antara lain adalah: ${ }^{7}$

a. Putusan hakim sebagai perwujudan upaya untuk mencegah dan menyelesaikan konflik. Di sini putusan hakim ditekankan pada fungsi mekanisme pengintegrasian masyarakat dengan mencegah konflik dan menyelesaikan atau mengatasinya dengan cara damai dan tertib apabila konflik telah terjadi;

b. Putusan hakim sebagai perwujudan upaya penemuan hukum. Dalam hal demikian putusan hakim ditekankan pada hubungan fungsi dan tugas hakim dengan undang-undang yang ada. Arti penting pandangan ini terletak pada hubungan pelaksanaan tugas hakim dengan undang-undang yang tidak selalu lengkap selengkap-lengkapnya dan tidak selalu jelas sejelas-jelasnya, karena tertinggal oleh perkembangan masyarakat yang lebih cepat;

c. Putusan hakim sebagai perwujudan law as 'a tool of social engineering. Di sini putusan hakim ditekankan pada fungsi pengstrukturan kembali suatu masyarakat yang di dasarkan pada tatanan dan nilai-nilai tertentu untuk di tujukan kepada masyarakat baru.

Dengan belum diakomodirnya alat bukti elektronik secara formal dalam ketentuan acara perdata, akan menyulitkan bagi hakim dalam menyelesaikan dan memutus sengketa apabila para pihak mengajukan dokumen elektronik sebagai bukti atau mengajukan pemeriksaan saksi dengan menggunakan teleconference, karena belum ada aturannya. Akan tetapi hal ini tidak dapat dijadikan alasan oleh hakim untuk tidak menerima serta memeriksa dan memutus perkara yang diajukan kepadanya sekalipun dengan dalih undang-undangnya tidak jelas atau belum ada pengaturannya.

Hal ini sesuai dengan asas Ius Curia Novit yang terkandung dalam Pasal 10 UU Kekuasaan kehakiman yang menyebutkan bahwa hakim tidak boleh menolak untuk memeriksa dan memutus perkara yang diajukan kepadanya sekalipun dengan dalih hukumnya tidak jelas atau tidak ada. Karenanya hakim harus tetap menerima untuk memeriksa dan memutus suatu perkara yang diajukan kepadanya sekalipun tidak ada undang - undangnya, untuk itu hakim harus melakukan penemuan hukum.

\footnotetext{
7 Sunaryati Hartono, Peranan Hakim Dalam Proses Pembentukan Hukum, Majalah Hukum Nasional, BPHN, No. 1, Jakarta: 2003, hlm. 8.
} 
Penemuan Hukum oleh Hakim Melalui Pembuktian dengan Menggunakan Bukti Elektronik

Selanjutnya Pasal 5 ayat (1) UU Kekuasaan Kehakiman menyatakan bahwa hakim wajib menggali, mengikuti dan memahami nilai-nilai hukum dan rasa keadilan yang hidup alam masyarakat. Sekalipun undang-undangnya tidak jelas atau tidak ada, namun hakim harus berupaya menemukan hukumnya, karena hakim memutus perkara berdasarkan hukum yang terdiri dari hukum tertulis (undang-undang) dan hukum tidak tertulis (nilai-nilai hukum yang hidup dalam masyarakat). Dengan demikian, tugas utama dari hakim adalah menemukan hukum melalui penyelesaian pemeriksaan suatu perkara yang diajukan ke pengadilan. Dalam mengadili suatu perkara, hakim harus melakukan tiga tahapan tindakan, yaitu:

Pertama hakim mengkonstatir, berarti melihat, mengakui dan membenarkan telah terjadinya peristiwa yang diajukan. Untuk sampai pada konstatering demikian itu, hakim harus mempunyai kepastian akan kebenaran peristiwa yang dikonstatirnya, Hakim harus melakukan pembuktian dengan alat-alat bukti untuk mendapatkan kepastian tentang kebenaran peristiwa yang diajukan kepadanya. Jadi mengkonstatir peristiwa berarti sekaligus juga membuktikan atau menganggap telah terbuktinya peristiwa yang bersangkutan.

Kedua, hakim harus mengkualifikasikan peristiwanya, yaitu menilai peristiwa yang telah dianggap benar-benar terjadi termasuk menemukan hukumnya bagi peristiwa yang telah dikonstatir. Untuk menemukan hukumnya, hakim sering melakukan penerapan hukum terhadap peristiwanya. Jadi mengkualifikasikan pada umumnya berarti menemukan hukumnya dengan jalan menerapkan peraturan hukum terhadap peristiwanya. Tetapi adakalanya peraturan hukumnya tidak tegas atau tidak jelas, maka dalam hal demikian hakim bukan hanya harus menemukan hukum tetapi juga harus menciptakan hukumnya sendiri. Hakim harus berani menciptakan hukum yang tidak bertentangan dengan keseluruhan sistem perundang-undangan dan yang memenuhi kebutuhan masyarakat. Pada ahirnya hakim harus mengkonstitusikan atau memberikan konstitusinya, berarti bahwa hakim menetapkan hukumnya kepada peristiwa yang bersangkutan.

Ketiga, penggunaan asas-asas hukum itu penting bagi hakim oleh karena membantunya dalam melakukan penafsiran dogmatis dan penerapan suatu undang - undang secara analogi terhadap peristiwa nyata. Asas-asas hukum, karena sifatnya yang umum maka tidak dapat diterapkan secara langsung pada peristiwa konkrit. Oleh karena itu, asas-asas hukum pada hakikatnya merupakan pedoman bagi hakim dalam memeriksa dan memutus suatu perkara.

Berdasarkan penjelasan di atas, permasalahan dokumen elektronik sebagai alat bukti di pengadilan yang sampai saat ini belum diatur secara formal, tidak dapat dijadikan alasan oleh hakim untuk tidak menyelesaikan sengketa yang alat buktinya berupa bukti elektronik, karena pada dasarnya hakim dilarang menolak untuk mengadili suatu perkara yang diajukan kepadanya dengan

\footnotetext{
8 Sudikno Mertokusumo, Hukum Acara Perdata Indonesia. Edisi VI, Liberty, Yogyakarta: 2004, hlm. 110. bandingkan Jimly Asshiddiqie, Aspek-Aspek Perkembangan Kekuasaan Kehakiman di Indonesia, Yogyakarta: UII Press Yogyakarta: 2005, hlm. 127-130.
} 
dalih belum ada pengaturan hukumnya. Selain itu hakim juga dituntut untuk melakukan penemuan hukum (rechtsvinding) dengan mengkaji norma-norma yang tumbuh dalam masyarakat untuk menyelesaikan sengketa.

Dalam hukum acara perdata dikenal beberapa teori penemuan hukum yang dapat digunakan oleh hakim dalam menemukan hukum. Penemuan hukum tidak dapat dilakukan tanpa aturan yang benar, melainkan harus tetap berdasarkan metode atau aturan permainan yang telah ditentukan. Dalam proses penyelesaian sengketa melalui pengadilan, yang melakukan penemuan hukum adalah hakim yang menerapkan hukum acara.

Sebagaimana telah dikemukakan sebelumnya bahwa hakim dalam melakukan penemuan hukum, harus melakukan tahapan-tahapan sebagai berikut: pertama mengkonstatir peristiwa konkrit, yaitu menyatakan bahwa benar telah terjadi suatu peristiwa melalui proses pembuktian. Setelah peristiwanya dibuktikan maka harus dicarikan hukumnya (penemuan hukum) untuk kemudian diterapkan pada peristiwa konkritnya. Jadi penemuan hukum bukanlah merupakan suatu kegiatan yang berdiri sendiri, tetapi merupakan kegiatan yang runtut dan berkesinambungan dengan proses pembuktian.

\section{Sistem Hukum Acara Perdata Mengakomodasi Pengaturan Bukti Elektronik di Indonesia Berdasarkan UU Informasi dan Transaksi Elektronik}

Menurut sistem HIR, dalam acara perdata hakim terikat pada alat-alat bukti yang sah, yang berarti bahwa hakim hanya boleh mengambil keputusan (menjatuhkan putusan) berdasarkan alatalat bukti yang ditentukan oleh undang-undang saja. Alat bukti dalam acara perdata yang disebutkan oleh undang-undang, diatur dalam Pasal 164 HIR, 284 RBg dan 1866 BW.

Pembuktian alat bukti elektronik sangat penting dalam hukum acara di Indonesia, terutama dalam hukum acara perdata. Hal ini disebabkan karena hukum acara perdata yang bersifat mencari kebenaran formal saja, artinya apa yang benar atau menurut apa yang diajukan para pihak yang bersengketa. Alat bukti elektronik dapat mempunyai kekuatan hukum jika informasi dapat dijamin keutuhannya, dapat dipertanggungjawabkan, dapat diakses dan dapat ditampilkan sehingga menerangkan suatu keadaan. ${ }^{9}$

Sebelum terbitnya UU ITE, eksistensi alat bukti elektronik sebenarnya telah tersebar dalam beberapa peraturan perundang-undangan, yaitu Undang-Undang Nomor 8 Tahun 1997 tentang Dokumen Perusahaan, Undang-Undang Nomor 15 Tahun 2003 tentang Penetapan Peraturan Pemerintah Pengganti Undang-Undang No. 1 Tahun 2002 tentang Pemberantasan Tindak Pidana Terorisme, Undang-Undang Nomor 15 Tahun 2002 tentang Tindak Pidana Pencucian Uang

\footnotetext{
9 Karjono, Perjanjian Lisensi Pengalihan Hak Cipta Program Komputer Transaksi Elektronik, Alumni, Bandung: 2012, hlm. 237.
} 
Penemuan Hukum oleh Hakim Melalui Pembuktian dengan Menggunakan Bukti Elektronik

sebagaimana telah diubah dalam UU No. 15 Tahun 2003, Undang-Undang Nomor 31 Tahun 1999 tentang Pemberantasan Tindak Pidana Korupsi sebagaimana diubah dengan UU No. 20 Tahun 2001, Undang-Undang Nomor 30 Tahun 2002 tentang Komisi Pemberantasan Korupsi. Namun, eksistensi alat bukti elektronik diakui sebagai alat bukti yang sah, semakin diperkuat dengan terbitnya UU ITE, yaitu dalam Pasal 5 UU ITE, yang menyebutkan ${ }^{10}$ :

“(1) Informasi Elektronik dan/atau Dokumen Elektronik dan/atau hasil cetaknya merupakan alat bukti hukum yang sah

(2) Informasi Elektronik dan/atau Dokumen Elektronik dan/atau hasil cetaknya sebagaimana dimaksud pada ayat (1) merupakan perluasan dari alat bukti yang sah sesuai dengan Hukum Acara yang berlaku di Indonesia"

Hal di atas seyogyanya bersesuaian dengan pengaturan UNCITRAL Model Law on Electronic Commerce yang menetapkan beberapa prinsip hukum, yaitu ${ }^{11}$ :

a. Segala informasi elektronik dalam bentuk data elektronik dapat dikatakan memiliki akibat hukum, keabsahan ataupun kekuatan hukum;

b. Dalam hal hukum mengharuskan adanya sesuatu informasi maka harus dalam bentuk tertulis, harus dianggap memenuhi syarat untuk itu;

c. Dalam hal tanda tangan maka sesuatu tanda tangan elektronik merupakan tangan tangan yang sah;

d. Dalam hal ketentuan pembuktian dari data yang bersangkutan dari data massage memiliki kekuatan pembuktian.

Singapore Electronic Transaction tahun 1998, menggariskan masalah hukum yang berkaitan dengan $e$ - commerce:

a. Tidak ada perbedaan antara data elektronik dengan dokumen kertas;

b. Suatu data elektronik dapat digantikan suatu dokumen tertulis;

c. Para pihak dapat melakukan kontrak secara elektronik;

d. Suatu data elektronik dapat merupakan alat bukti dipengadilan; e. Jika suatu data elektronik telah diterima oleh para pihak maka harus bertindak sebagai mana kesepakatan yang terdapat pada data tersebut.

Apabila mencermati ketentuan alat-alat bukti yang tercantum dalam HIR/RBg, sesungguhnya hakim dapat memeriksa/menggunakan dokumen elektronik sebagai alat bukti, yaitu antara lain dengan bantuan keterangan seorang ahli (saksi ahli) yang mengetahui dan mengerti tentang

\footnotetext{
${ }^{10}$ Moh. Nafri, “Dokumen Elektronik sebagai Alat Bukti dalam Hukum Acara Perdata di Indonesia”, Maleo Law Journal, Vol. 3, No. 1, 2019, hlm. 41-42.

${ }^{11}$ Muhammad Iqbal Tarigan, "Dokumen Elektronik sebagai Alat Bukti dalam Perspektif Pembaruan Hukum Acara Perdata Indonesia", USU Law Journal, Vol. 4 No. 1, Januari 2016, hlm. 128.
} 
dokumen elektronik tersebut, sekalipun hakim tidak harus menerima atau terikat dengan keterangan ahli tersebut, dengan kata lain kekuatan pembuktiannya bebas (diserahkan sepenuhnya kepada hakim). Selain itu, hakim juga dapat menggunakan alat bukti persangkaan-persangkaan yang ditarik oleh hakim dari persidangan, dalam memeriksa dokumen elektronik sebagai alat bukti.

Keterangan saksi ahli dapat memberikan atau menambah pengetahuan bagi hakim tentang sesuatu hal yang harus dibuktikan, sehingga apabila misalnya dalam sengketa perbankan ada pihak yang berperkara mengajukan dokumen elektronik sebagai buktinya, maka hakim dapat meminta keterangan ahli perbankan untuk menjelaskan mengenai dokumen elektronik tersebut berkaitan dengan perannya sebagai alat bukti. Dengan demikian keterangan saksi ahli dapat menambah pengetahuan bagi hakim yang dapat dijadikan dasar untuk melakukan penilaian terhadap bukti elektronik tersebut. Mengenai kekuatan buktinya sepenuhnya diserahkan kepada hakim.

Demikian pula halnya dengan persangkaan, karena melalui persangkaan hakim yang ditarik dari hal-hal yang terbukti di persidangan berdasarkan pada keterangan saksi-saksi (termasuk saksi ahli), dapat dijadikan dasar bagi hakim untuk menerima dokumen elektronik sebagai bukti di persidangan, dengan kekuatan pembuktian yang bebas dalam arti diserahkan sepenuhnya pada hakim.

Pengakuan Mahkamah Agung terhadap dokumen elektronik pada sistem peradilan pertama kali diketahui melalui Surat Edaran Mahkamah Agung (SEMA) Nomor 14 Tahun 2010 tentang Dokumen Elektronik sebagai Kelengkapan Permohonan Kasasi dan Peninjauan Kembali. SEMA ini bertujuan untuk meningkatkan efisiensi dan efektivitas proses minutasi berkas perkara serta menunjang pelaksanaan transparansi dan akuntabilitas serta pelayanan publik pada Mahkamah Agung dan Badan Peradilan di bawahnya. Namun SEMA ini tidaklah mengatur tentang dokumen elektronik sebagai alat bukti melainkan dokumen elektronik berupa putusan maupun dakwaan yang dimasukkan pada compact disc, flash disk/dikirim melalui email sebagai kelengkapan permohonan kasasi dan peninjauan kembali. SEMA ini telah mengalami perubahan berdasarkan SEMA 1 Tahun 2014 tentang Perubahan atas SEMA 14 Tahun 2010 tentang Dokumen Elektronik sebagai kelengkapan Permohonan Kasasi dan Peninjauan Kembali. Perubahan SEMA ini dilakukan berkaitan dengan sistem pemeriksaan berkas dari sistem bergiliran menjadi sistem baca bersama yang diarahkan secara elektronik. ${ }^{12}$

Di pengadilan terdapat dua kelompok hakim mengenai hal ini, yaitu ada hakim yang secara tegas menolak bukti elektronik sebagai alat bukti yang dapat diajukan ke pengadilan karena belum ada undang-undang yang mengaturnya. Akan tetapi ada pula kelompok hakim (umumnya hakim

\footnotetext{
12 Nurfauziah Maulidiyah, Yustria Novi Satriana, "Eksistensi Digital Evidence dalam Hukum Acara Perdata", Jurnal Cakrawala Hukum, Vol 10, No. 1 Juni 2019, hlm. 75.
} 
Penemuan Hukum oleh Hakim Melalui Pembuktian dengan Menggunakan Bukti Elektronik

pada Pengadilan Niaga) yang membuka diri untuk menerima keberadaan dokumen elektronik sebagai alat bukti yang dapat diajukan ke persidangan. ${ }^{13}$ Hakim-hakim di Pengadilan Niaga pada umumnya mulai menerima dokumen elektronik sebagai alat bukti, seperti misalnya dokumen perusahaan yang sudah berbentuk microfilm berdasarkan pada undang-undang Dokumen Perusahaan, tetapi dikelompokkan pada bukti tertentu. Artinya bahwa jika dapat dipertanggungjawabkan bahwa sesuai bukti surat lainnya (memenuhi syarat sebagai alat bukti surat pada umumnya), maka dokumen elektronik dapat diterima sebagai alat bukti.

Hal ini sejalan dengan apa yang disampaikan Mahkamah Agung RI dalam suratnya kepada Menteri Kehakiman tanggal 14 Januari 1988 No.39/TU/88/102/Pid, yang mengemukakan pendapatnya bahwa microfilm atau microfiche dapat dipergunakan sebagai alat bukti yang sah dalam perkara pidana di pengadilan menggantikan alat bukti surat, dengan catatan microfilm itu sebelumnya dijamin otentikasinya yang dapat ditelusuri kembali dari registrasi maupun berita acara. Terhadap penyelesaiam perkara perdata berlaku pula pendapat yang sama.

Permasalahannya selanjutnya adalah apakah suatu bukti berbentuk dokumen elektronik dapat dipersamakan dengan dokumen tertulis (surat) dan digunakan oleh para pihak dalam pembuktian, serta diterima oleh hakim sebagai alat bukti dalam penyelesaian sengketa melalui pengadilan. Kalau dikaji dari definisi surat yang diberikan oleh Sudikno Mertokusumo sebagaimana telah diuraikan sebelumnya, yaitu segala sesuatu yang memuat tanda-tanda bacaan dan dimaksudkan untuk mencurahkan isi hati atau untuk menyampaikan buah pikiran seseorang, dan dipergunakan sebagai pembuktian, maka tidak ada penjelasan bahwa tulisan atau surat itu harus ditulis di atas media kertas. Jadi tidak memandang apakah ditulisnya di atas lembaran kertas atau pada bahan apapun tetap merupakan surat.

Potret atau gambar tidak memuat tanda baca atau buah pikiran, demikian pula denah atau peta, meskipun ada tanda-tanda bacanya tetapi tidak mengandung buah pikiran atau isi hati seseorang. Itu semua hanya sekedar merupakan barang atau benda untuk meyakinkan saja (demonstrative evidence). Sebaliknya sepucuk surat yang berisikan curahan hati yang diajukan di muka sidang pengadilan ada kemungkinan tidak berfungsi sebagai alat bukti tertulis atau surat, tetapi sebagai benda untuk meyakinkan saja karena bukan kebenaran isi atau bunyi surat itu yang seharusnya dibuktikan atau digunakan sebagai bukti, melainkan eksistensi surat itu sendiri menjadi bukti, sebagai barang yang dicuri misalnya. ${ }^{14}$

Kaitannya dengan penggunaan media elektronik sebagai penyimpan pesan, maka menurut penulis dapatlah dianalogikan bahwa penulisan surat di atas media (material) elektronik (dokumen elektronik) juga dapat dikategorikan sebagai alat bukti surat (yang bukan akta) dengan dilakukan

\footnotetext{
${ }^{13}$ Hasil wawancara dengan Heru Pramono, Hakim Niaga, Pengadilan Negeri Jakarta Pusat, 5-12-2007.

${ }^{14}$ Sudikno Mertokusumo, Op.Cit., hlm. 142.
} 
upaya-upaya tertentu. ${ }^{15} \mathrm{Hal}$ ini sejalan dengan apa yang dikemukakan oleh Herlien Budiono bahwa, "Tidak menjadi masalah mengenai di atas material apa tulisan tersebut harus dituliskan." 16

Pada umumnya pengajuan alat bukti surat/akta atau dokumen tertulis disertai dengan bukti keterangan saksi untuk menambah keyakinan hakim dalam menilai kebenaran peristiwa di persidangan. Saksi harus memberikan atau menyampaikan keterangannya kepada hakim di muka persidangan secara lisan (tidak boleh secara tertulis) dan pribadi (langsung disampaikan sendiri oleh saksi dan tidak boleh mewakilkan), mengenai kejadian atau peristiwa yang dialaminya sendiri atau dilihatnya secara langsung.

Perkembangan dewasa ini, dapat dilakukan pemeriksaan saksi oleh majelis hakim terhadap saksi yang berada di luar gedung pengadilan tempat persidangan tersebut digelar, bahkan saksi berada di luar negeri yang karena satu dan lain hal tidak dapat dihadirkan di muka persidangan. Kemajuan teknologi informasi dan komunikasi telah berhasil memfasilitasi pemeriksaan saksi jarak jauh ini dengan menggunakan perangkat elektronik yang dinamakan video conference untuk menggunakan teleconference.

Kalau dikaji secara objektif, pemeriksaan saksi melalui teleconference pada dasarnya sama dengan pemeriksaan saksi biasa yang dilakukan di ruang persidangan, dalam hal saksi memberikan keterangannya secara lisan dan pribadi langsung di muka persidangan. Perbedaannya terletak pada keberadaan saksi yang tidak secara fisik ada di ruang sidang pengadilan tempat perkara digelar, melainkan saksi berada di dunia maya yang secara visual hadir di ruang sidang pemeriksaan perkara.

Penulis berpendapat bahwa pemeriksaan saksi melalui teleconference tidaklah bertentangan dengan hukum acara yang berlaku (HIR/RBg) yang menentukan bahwa saksi harus memberikan keterangannya secara lisan dan pribadi langsung di muka persidangan (sebagaimana tersirat dalam Pasal 140 HIR/166 RBg ayat: 1), hanya terdapat perbedaan dalam hal tempat keberadaan saksi antara dunia maya dan nyata. ${ }^{17}$

Dengan demikian meskipun tentang bukti elektronik ini belum diatur dalam bentuk hukum formal (hukum acara), namun hakim tetap harus mengadili dan memutus perkara yang diajukan kepadanya dengan pembuktian menggunakan bukti elektronik dengan cara melakukan penemuan hukum. Menurut sistem hukum acara perdata yang berlaku, pembuktian itu baru sah bila menggunakan alat bukti yang sudah ditentukan dalam peraturan yang berlaku, sedangkan hakim memutus didasarkan pada hasil pembuktian. Meskipun tentang bukti elektronik ini tidak diatur dlm HIR namun secara materiil sudah diatur dalam UU Informasi dan Transaksi Elektronik serta UU Dokumen Perusahaan. Akan tetapi sesungguhnya sekalipun tidak ada pengaturannya secara tegas,

\footnotetext{
${ }^{15}$ Efa Laela Fakhriah, Bukti Elektronik Dalam Sistem Pembuktian Perdata, Alumni, Bandung: 2011, hlm. 122.

${ }^{16}$ Herlien Budiono, Kumpulan Tulisan Hukum Perdata Di Bidang Kenotariatan, Citra Aditya Bakti, Bandung: 2007, hlm. 217.

${ }^{17}$ Efa Laela Fakhriah, Op.Cit., hlm. 127.
} 
Penemuan Hukum oleh Hakim Melalui Pembuktian dengan Menggunakan Bukti Elektronik

tetap hakim dapat melakukan penemuan hukum dengan metode analogi atau penafsiran terhadap bukti yang bersifat elektronik agar dapat digunakan sebagai alat bu kti di persidangan.

\section{PENUTUP}

Hukum pembuktian (hukum acara perdata) belum mengatur dokumen elektronik sebagai alat bukti, sedangkan dalam praktiknya di masyarakat alat bukti elektronik sudah banyak digunakan, terutama dalam transaksi bisnis modern. Sementara itu menurut sistem hukum pembuktian perdata, hakim terikat pada alat-alat bukti yang sah, yang berarti bahwa hakim hanya boleh mengambil keputusan berdasarkan pembuktian dengan menggunakan alat-alat bukti yang telah ditentukan oleh undang-undang saja. Sampai saat ini alat bukti yang diatur dalam undang-undang adalah surat, saksi, persangkaan-persangkaan, pengakuan, sumpah, pemeriksaan setempat, keterangan saksi ahli; sedangkan mengenai bukti elektronik secara materiil sudah diatur dalam UU Dokumen Perusahaan dan UU Informasi dan Transaksi Elektronik, bukan dalam bentuk hukum acara sehingga tidak mengikat hakim dalam penyelesaian sengketa melalui pengadilan.

Hal memeriksa perkara yang pembuktiannya menggunakan bukti-bukti bersifat elektronik, karena hukum acara perdata (HIR) sebagai hukum formil tidak mengaturnya, maka hakim dapat mendasarkan pembuktian pada hukum materiil yang juga mengatur tentang hukum acara, dalam hal ini Undang-undang Informasi dan Transaksi Elektronik atau Undang-undang Dokumen Perusahaan. Akan tetapi seandainya pun tidak ada peraturan materil yang mengatur tentang bukti elektronik sebagai alat bukti yang sah dipersidangan, atau hakim tidak mau mendasarkan pembuktian pada hukum materiil, hakim dapat melakukan penemuan hukum dengan cara analogi atau penafsiran hukum terhadap bukti yang bersifat elektronik agar dapat digunakan sebagai alat bukti di persidangan sebagaimana halnya alat bukti yang diatur dalam hukum acara perdata.

\section{DAFTAR PUSTAKA}

\section{Buku}

Efa Laela Fakhriah, Bukti Elektronik Dalam Sistem Pembuktian Perdata, Alumni, Bandung: 2011.

Herlien Budiono, Kumpulan Tulisan Hukum Perdata Di Bidang Kenotariatan, Citra Aditya Bakti, Bandung: 2007.

Jimly Asshiddiqie, Aspek-Aspek Perkembangan Kekuasaan Kehakiman di Indonesia, UII Press Yogyakarta, Yogyakarta: 2005.

Karjono, Perjanjian Lisensi Pengalihan Hak Cipta Program Komputer Transaksi Elektronik, Alumni, Bandung: 2012. 
Sudikno Mertokusumo, Hukum Acara Perdata Indonesia. Edisi VI, Liberty, Yogyakarta: 2004.

Teguh Prasetyo-Abdul Halim Barkatullah, IImu Hukum \& Filsafat Hukum, Pustaka Pelajar, Yogyakarta: 2007.

\section{Jurnal}

Budi Suhariyanto, “Eksistensi Pembentukan Hukum oleh Hakim dalam Dinamuka Politik Legislasi di Indonesia", Jurnal Rechsvinding, Vol. 4, No. 3, Desember 2015.

Elisabeth Nurhaini Butarbutar, "Arti Pentingnya Pembuktian dalam Proses Penemuan Hukum di Peradilan Perdata", Jurnal Mimbar Hukum, Vol. 22, No. 2, 2010.

Moh. Nafri, "Dokumen Elektronik sebagai Alat Bukti dalam Hukum Acara Perdata di Indonesia", Maleo Law Journal, Vol. 3, No. 1, 2019.

Muhammad Iqbal Tarigan, "Dokumen Elektronik sebagai Alat Bukti dalam Perspektif Pembaruan Hukum Acara Perdata Indonesia", USU Law Journal, Vol. 4, No. 1, Januari 2016.

Nurfauziah Maulidiyah, Yustria Novi Satriana, "Eksistensi Digital Evidence dalam Hukum Acara Perdata", Jurnal Cakrawala Hukum, Vol. 10, No. 1 Juni 2019.

Sunaryati Hartono, "Peranan Hakim Dalam Proses Pembentukan Hukum”, Majalah Hukum Nasional, BPHN, No.1, Jakarta, 2003.

\section{Sumber Lain}

Hasil wawancara dengan Heru Pramono, Hakim Niaga, Pengadilan Negeri Jakarta Pusat, 5-12-2007. Yurisprudensi, Electriciteits Arrest, 23 Mei 1921. 